\title{
Algicidal bacteria in particle-associated form and in free-living form during a diatom bloom in the Seto Inland Sea, Japan
}

\author{
Jung-Hwan Park ${ }^{1}$, Ikuo Yoshinaga ${ }^{2, *}$, Tetsuya Nishikawa ${ }^{3}$, Ichiro Imai ${ }^{1,4, * *}$ \\ ${ }^{1}$ Laboratory of Marine Environmental Microbiology and ${ }^{2}$ Laboratory of Marine Microbiology, Division of Applied \\ Biosciences, Graduate School of Agriculture, Kyoto University, Kyoto 606-8502, Japan \\ ${ }^{3}$ Tajima Fisheries Technology Institute, Hyogo Prefectural Technology Center for Agriculture, Forestry and Fisheries, \\ Kasumi, Kami, Mikata, Hyogo 669-6541, Japan
}

${ }^{4}$ Present address: Plankton Laboratory, Division of Marine Biology and Environmental Science, Graduate School of Fisheries Sciences, Hokkaido University, Hakodate, Hokkaido 041-8611, Japan

\begin{abstract}
To analyze the interrelated dynamics of microalgae and algicidal bacteria (i.e. bacteria that kill and utilize microalgal cells) in a seawater environment, we investigated particle-associated and free-living algicidal bacteria during a diatom bloom in the Seto Inland Sea (Japan) in the summer of 2005. A conventional most probable number (MPN) protocol revealed that bacteria that are algicidal against the harmful microalga Chattonella antiqua (Raphidophyceae) increased in number towards the end of the diatom bloom, during which only a few cells of Chattonella species were observed. Relatively abundant heterotrophic bacteria were present during the bloom period, indicating that the bloom promoted the growth and activity of the ambient bacterial population, including algicidal bacteria. The algicidal abilities of 487 strains isolated from the particle-associated bacteria (PAB) fraction and 249 strains isolated from the free-living bacteria (FLB) fraction were tested against axenic cultures of 3 dinoflagellates and 3 raphidophycean flagellates. About half of the PAB isolates (231/487 strains) showed algicidal activity against 1 or more tested microalgae, while only $22 \%$ of the FLB isolates (55/249 strains) were algicidal. Eighty percent of algicidal bacteria from the PAB fraction could kill multiple species of tested microalgae, whereas most of the algicidal bacteria from the FLB fraction killed only a single species. These observations suggest that diatom blooms provide a habitat for algicidal bacteria with a wide prey range that potentially limit harmful algal blooms caused by dinoflagellates and raphidophycean flagellates.
\end{abstract}

KEY WORDS: Algicidal bacteria $\cdot$ Particle-associated bacteria $\cdot$ Free-living bacteria $\cdot$ Harmful algal bloom

\section{INTRODUCTION}

Changes in species composition in phytoplankton communities and developments of phytoplankton blooms are regulated by various physicochemical and biological factors in seawater environments (Marcarelli et al. 2006, Pannard et al. 2008). In particular, phytoplankton cell death due to living organisms, such as grazing by zooplankton (Buskey 2008), killing and growth inhibition by some bacteria (Imai et al. 1998, Yoshinaga et al. 1998, Mayali \& Doucette 2002), and viral infection (Nagasaki \& Brussaard 2008), are considered to affect phytoplankton communities more species-specifically than temperature, salinity, nutrients, and other physicochemical factors. Algicidal bacteria, which can kill microalgal cells in co-cultivation and utilize the resulting organic matter for their own growth, are among the most important agents causing 
the drastic termination of phytoplankton blooms (Imai et al. 1993, 1998, Kim et al. 2008). Such characteristics of algicidal bacteria have inspired scientists to apply them as a tool for controlling and mitigating harmful algal blooms (HABs) that occur naturally.

Several strains of algicidal bacteria have been isolated to date, and analyses of their $16 \mathrm{~S}$ ribosomal RNA gene sequences have revealed that a variety of bacterial genera, such as Cytophaga (Imai et al. 1993), Flavobacterium (Fukami et al. 1997), Alteromonas (Yoshinaga et al. 1998), Pseudoalteromonas (Mitsutani et al. 2001), and Vibrio (Yoshinaga et al. 1995), can cause mortality in several species of marine microalgae including dinoflagellates, raphidophycean flagellates, and diatoms. Furthermore, investigations in cocultivation experiments have revealed the existence of 2 types of algicidal mechanisms: 'direct attack' (Imai \& Kimura 2008) and 'algicide production' (Doucette et al. 1999). In natural environments, a wide variety of algicidal bacteria are present and should influence the development and decay process of HABs (Yoshinaga et al. 1997, Imai et al. 1998). However, there is a paucity of information on the ecology of algicidal bacterial populations, especially on their life style and habitat.

Bacteria in seawater are often classified into 2 different groups, viz. particle-associated bacteria (PAB) and free-living bacteria (FLB), according to their association with particulate organic matter (Bidle \& Fletcher 1995). Owing to the prerequisites of substrata, the type of particles available in seawater regulates the cell abundance, species diversity, and sedimentation rate of PAB (Grossart et al. 2003, Jackson \& Weeks 2008). Particles floating in seawater are from heterogeneous sources including marine flora, fauna, and detritus. Algal cells, which change constantly in quantity and quality, can be a major source of particulate matter during a blooming period, providing substrata for $\mathrm{PAB}$ groups. The algal cells not only provide the physical substrata for PAB but also stimulate growth of heterotrophic bacteria on and near the cell, with algal exudates as an important carbon source. Moreover, the cell activity of $\mathrm{PAB}$, such as exoenzymatic hydrolysis of organic particles and polymers, is known to be 2 to 3 orders of magnitude higher than that of FLB in the surrounding water, creating micro-scale 'hot-spots' (Long \& Azam 2001). Microalgal cells in seawater should influence the ambient bacterial assemblages in $\mathrm{PAB}$ and FLB fractions, including algicidal bacteria.

In the present study, we isolated PAB and FLB from seawater collected in the Seto Inland Sea (Japan) in summer, when a microalgal bloom composed of several species of diatoms occurred, and compared the algicidal activities of PAB and FLB isolates against several species of harmful algae belonging to dinoflagel- lates and raphidophycean flagellates. At the same time, we enumerated algicidal bacteria by the conventional most probable number (MPN) method (Imai et al. 1998). We provide new insight into the habitat and dynamics of algicidal bacterial populations and their potential significance for the prevention of HABs.

\section{MATERIALS AND METHODS}

Sampling. Sampling was performed weekly from 27 June to 15 August 2005 at Station (Stn) H31 (coastal site, water depth of $10 \mathrm{~m}$ ) and Stn H2 (offshore site, water depth of $20 \mathrm{~m}$ ) located in Harima-Nada, eastern Seto Inland Sea, Japan (Fig. 1). Seawater samples at

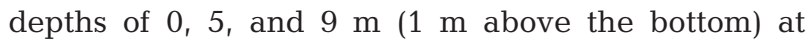
Stn H31 and of 0, 5, and $10 \mathrm{~m}$ at Stn H2 were collected using either a Kitahara water sampler or a Van Dorn water sampler. The samples were transported to the laboratory at $5^{\circ} \mathrm{C}$ under dark conditions. Water temperature and salinity were measured at sites with a submersible CTD (model ACL215, JFE ALEC). Concentrations of dissolved inorganic nitrogen (DIN: $\mathrm{NO}_{3}-$ $\left.\mathrm{N}+\mathrm{NO}_{2}-\mathrm{N}+\mathrm{NH}_{4}-\mathrm{N}\right)$, phosphate $\left(\mathrm{PO}_{4}\right)$, and silicic acid $\left(\mathrm{SiO}_{2}-\mathrm{Si}\right)$ were analyzed with a TRAACS-800 (BL-TEC K.K.), in accordance with the protocols of Manabe \& Tanda (1986). To represent the total biomass of microalgae, we determined the concentration of chlorophyll a (chl a; Imai et al. 2001). The appropriate volume of each seawater sample was filtered through a glass fiber filter (Whatman GF/C) immediately after sampling, and the filters were kept at $-20^{\circ} \mathrm{C}$ in the dark. Chl a was extracted in $90 \%$ acetone and quantified with a spectrofluorometer (model F-2000, Hitachi). Phytoplankton in each seawater sample was observed under a light microscope without fixation within $24 \mathrm{~h}$ after sampling. Three species of HAB-causing dinofla-

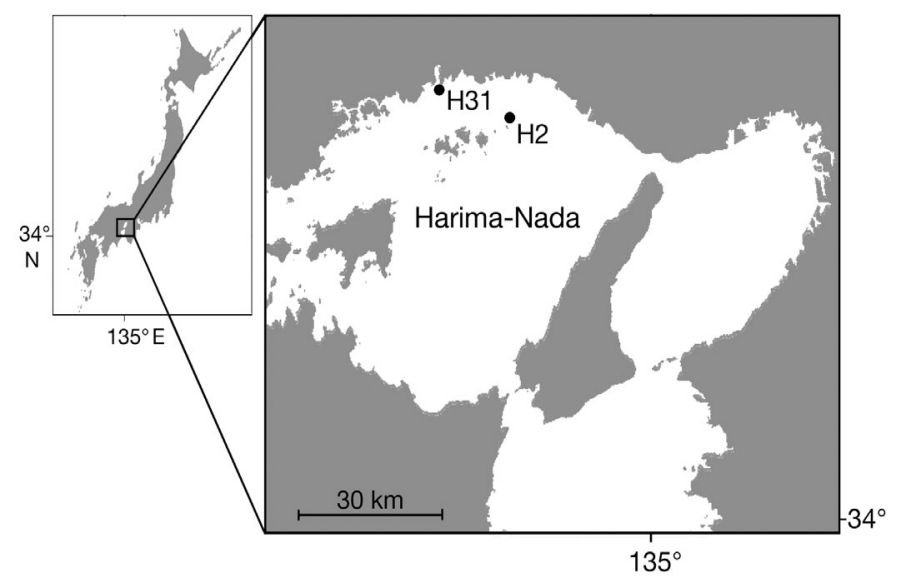

Fig. 1. Sampling stations in Harima-Nada, the eastern area of the Seto Inland Sea of Japan 
gellates, viz. Cochlodinium polykrikoides (fish killer), Karenia mikimotoi (fish killer), and Heterocapsa circularisquama (bivalve killer), and 3 fish-killing raphidophycean flagellates (Chattonella antiqua, C. marina, and C. ovata) were counted at every sampling occasion. The phytoplankton community structure in the surface water of Stns H2 and H31 on 4 July, during which a diatom bloom occurred, was also investigated and quantified.

Enumeration of algicidal bacteria. Algicidal bacteria were counted by the microplate-MPN method (Imai et al. 1998). Axenic cultures of 1 dinoflagellate (Heterocapsa circularisquama) and 3 raphidophycean flagellates (Chattonella antiqua, Heterosigma akashiwo, and Fibrocapsa japonica) were used in the present study as target algae for algicidal bacteria. These algae were cultivated in a modified SWM3 medium (Yoshinaga et al. 1995) at $20^{\circ} \mathrm{C}$ under a light intensity of 100 to $150 \mu \mathrm{mol}$ photons $\mathrm{m}^{-2} \mathrm{~s}^{-1}$ with a $14 \mathrm{~h}$ light: $10 \mathrm{~h}$ dark cycle. Each seawater sample collected and transported to the laboratory was filtrated through $0.8 \mu \mathrm{m}$ pore size Nuclepore filters (Whatman) to exclude living organisms larger than bacteria, such as phytoplankton and zooplankton (grazers). The filtrate including bacterial particles was serially diluted with autoclaved seawater. A portion $(0.5 \mathrm{ml})$ of the diluted seawater was dispensed into wells of disposable sterilized 48-well microplates (Wako Pure Chemical Industries) in which $0.5 \mathrm{ml}$ of the axenic microalgal cultures of each species was dispensed in advance. The autoclaved seawater and the seawater filtrated through a $0.2 \mu \mathrm{m}$ pore size Nuclepore filter were inoculated as bacteria-free controls. The bacteria-microalgae co-cultures in the microplate wells were incubated under the same conditions as microalgal cultivation. Each microplate well was observed daily with an inverted microscope (Olympus KC40), and the wells in which $90 \%$ of microalgal cells were killed within $6 \mathrm{~d}$ of incubation were judged as being 'algicidal bacteria positive'. The MPN of algicidal bacteria in seawater samples was estimated by the number of algicidal-bacteria-positive wells at each dilution level, calculated using the protocol of the Bacteriological Analytical Manual of the US Food and Drug Administration (Blodgett 1998).

Enumeration and isolation of heterotrophic bacteria in particle-associated and free-living form. Prior to fractionation, the seawater samples were serially diluted 10-fold with autoclaved seawater. An aliquot $(10 \mathrm{ml})$ of seawater at each dilution was filtrated through a $0.8 \mu \mathrm{m}$ pore size Nuclepore filter, which was placed on an ST10 ${ }^{-1}$ agar plate (1 l seawater, $0.05 \mathrm{~g}$ yeast extract, $0.5 \mathrm{~g}$ tripticase peptone, $15 \mathrm{~g}$ agar; Yoshinaga et al. 1997) for the cultivation of PAB. A portion $(0.1 \mathrm{ml})$ of the filtrate in each dilution was also spread on the ST10 $0^{-1}$ agar plate for the cultivation of FLB.
After 2 wk of incubation at $20^{\circ} \mathrm{C}$ in the dark, colonyforming units (CFU) on the filters and the filtrates were counted to calculate the numbers of PAB and FLB in each seawater sample. For the isolation of $\mathrm{PAB}$ and FLB, colonies were picked and streaked again on a new ST10 $0^{-1}$ agar plate and cultivated under the same conditions. After repeating this streaking process twice, bacterial isolates were cultivated in the liquid ST $10^{-1}$ medium and preserved at $-70^{\circ} \mathrm{C}$ with $10 \%$ glycerol (final concentration).

Assay for algicidal activity. The algicidal abilities of PAB and FLB isolates were assayed against axenic cultures of 3 dinoflagellates (Cochlodinium polykrikoides, Karenia mikimotoi, and Heterocapsa circularisquama) and 3 raphidophycean flagellates (Chattonella antiqua, Heterosigma akashiwo, and Fibrocapsa japonica). C. polykrikoides and K. mikimotoi were cultivated in modified SWM3 medium at $25^{\circ} \mathrm{C}$ under the same light and dark conditions as the other microalgae. The $0.2 \mu \mathrm{l}$ (ca. $10^{4}$ to $10^{5}$ cells) cultures of PAB and FLB isolates were inoculated into the microalgal cultures $(0.5 \mathrm{ml})$ in wells of 48-well microplates and incubated for $6 \mathrm{~d}$ under the same conditions as for each microalga. After $6 \mathrm{~d}$ of co-cultivation with each bacterial isolate, microalgal cells were observed microscopically, and in cases where more than $90 \%$ of microalgal cells were killed (immobile) and/or lysed, we judged the bacteria to be algicidal activity positive.

\section{RESULTS}

\section{Environmental parameters}

The temperature of the surface seawater at both sites increased gradually from the beginning of the research (27 June) until 8 August. The seawater temperature at deeper layers $(10 \mathrm{~m}$ at Stn $\mathrm{H} 2$ and $9 \mathrm{~m}$ at Stn H31) fluctuated between 2 and $4^{\circ} \mathrm{C}$ lower than the temperature at the surface throughout the sampling period. Salinity profiles at Stns H2 and H31 demonstrated low salinity at the surface layer on 4 July at both sites. On that date, high concentrations of chl a (23.7 $\mu \mathrm{g} \mathrm{l}^{-1}$ at Stn $\mathrm{H} 2$ and $27.8 \mu \mathrm{g} \mathrm{l}^{-1}$ at Stn H31) were observed (Fig. 2).

DIN and dissolved inorganic phosphorus (DIP) in the surface layer fluctuated at low concentrations, less than $2 \mu \mathrm{M}$ and $0.2 \mu \mathrm{M}$, respectively, at both Stns H2 and H31. In contrast to the surface seawater, the seawater at the bottom at both sites contained higher concentrations of DIN and DIP. A relatively high concentration of silicic acid existed at the beginning of July at the surface at Stns H2 and H31, and was consumed by the diatoms that were present in abundance at the beginning of July. 
Microalgal community structure

Table 1 shows the species compositions of phytoplankton in surface seawater at Stns H2 and H31 on 4 July when chl a reached its maximum concentration.
Three species of diatoms, Skeletonema costatum, Thalassiosira spp., and Chaetoceros spp., were numerically dominant. The concentrations of Skeletonema spp. reached 7500 cells $\mathrm{ml}^{-1}$ and 4250 cells $\mathrm{ml}^{-1}$, and Thalassiosira spp. reached 4300 cells $\mathrm{ml}^{-1}$, and
Station $\mathbf{H 2}$

Water temperature $\left({ }^{\circ} \mathrm{C}\right)$
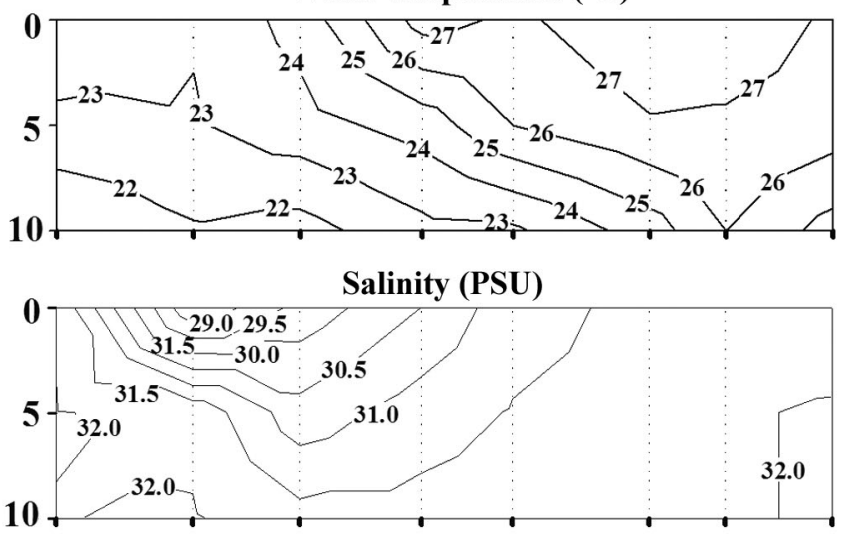

Dissolved inorganic nitrogen $(\mu M)$

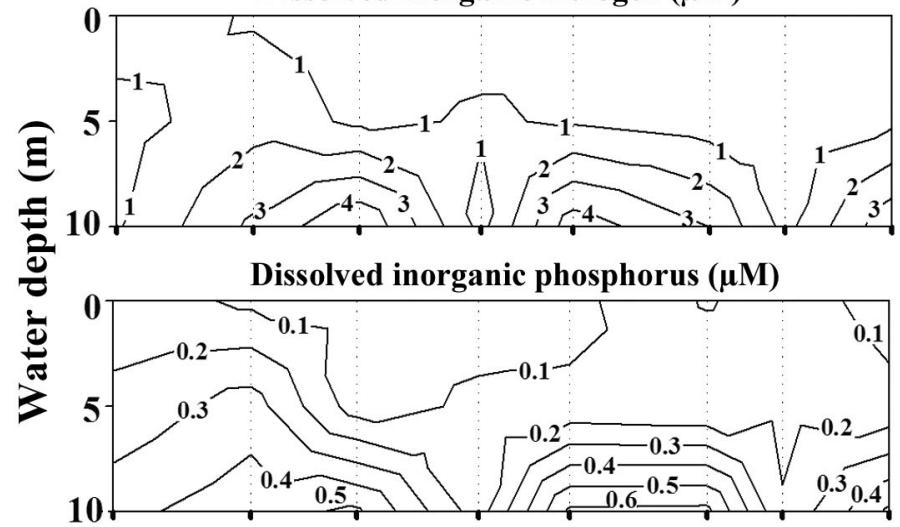

Silicic acid $(\mu \mathrm{M})$
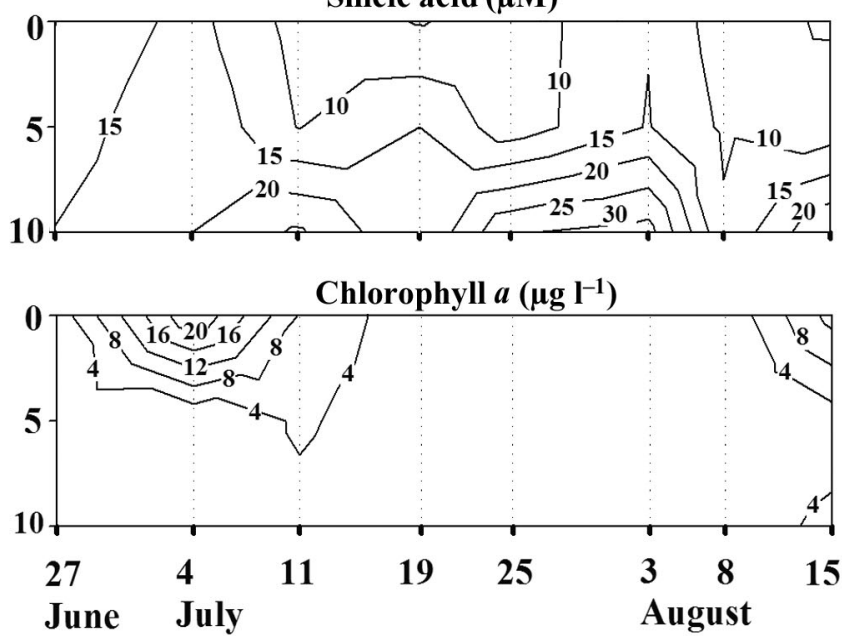

Station H31

Water temperature $\left({ }^{\circ} \mathrm{C}\right)$

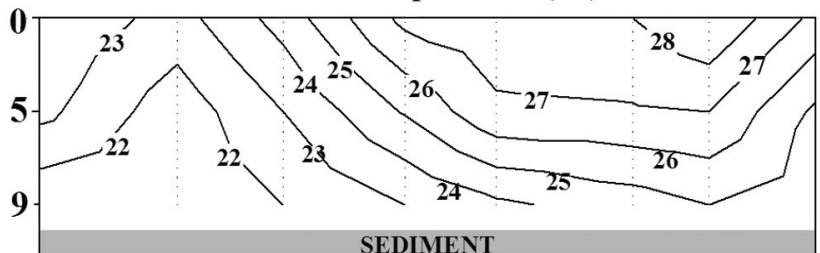

Salinity (PSU)

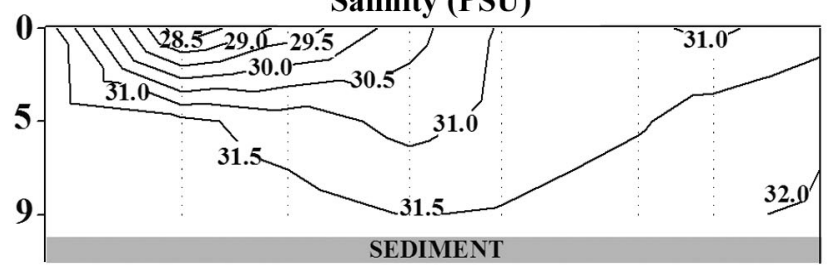

Dissolved inorganic nitrogen $(\mu \mathrm{M})$

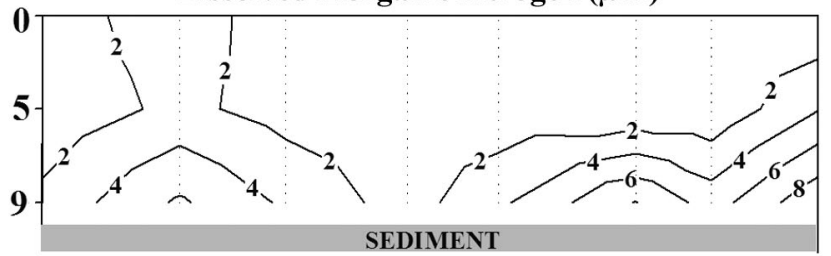

Dissolved inorganic phosphorus $(\mu \mathrm{M})$

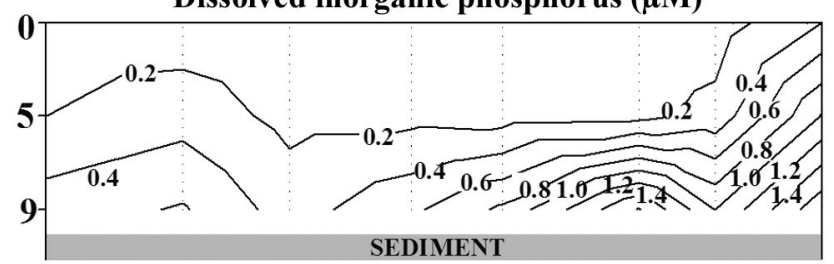

Silicic acid $(\mu \mathrm{M})$

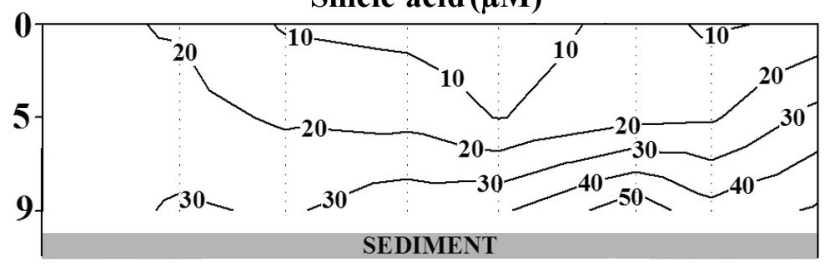

Chlorophyll $a\left(\mu \mathrm{g} \mathrm{I}^{-1}\right)$

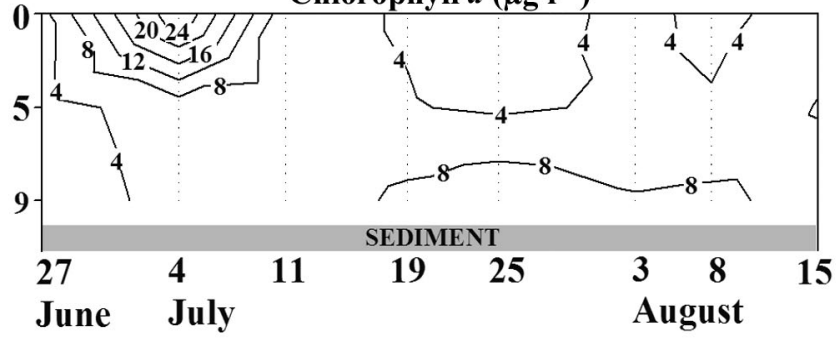

Fig. 2. Water temperature, salinity, and concentrations of dissolved inorganic nitrogen, dissolved inorganic phosphorus, dissolved silicic acid, and chlorophyll $a$ at depths 0 to $10 \mathrm{~m}$ at Stn H2 and 0 to $9 \mathrm{~m}$ at Stn H31 in Harima-Nada from 27 June to 15 August 2005 
Table 1. Species composition of the microalgal bloom that occurred on 4 July 2005 in the surface layer of seawater at Stns H2 and H31 (cells ml ${ }^{-1}$ )

\begin{tabular}{|c|c|c|}
\hline Species & $\mathrm{H} 2$ & H31 \\
\hline \multicolumn{3}{|l|}{ Bacillariophyceae } \\
\hline Skeletonema spp. & 7500 & 4250 \\
\hline Thalassiosira spp. & 4300 & 5400 \\
\hline Leptocylindrus danicus & 6 & 6 \\
\hline Eucampia zodiacus & 11 & 4 \\
\hline Hemiaulus sinensis & 8 & 0 \\
\hline Chaetoceros densus & 0 & 18 \\
\hline Chaetoceros spp. & 1000 & 400 \\
\hline Neodelphineis pelagica & 4 & 53 \\
\hline Thalassionema nitzschioides & 17 & 7 \\
\hline Pseudo-nitzschia spp. & 12 & 4 \\
\hline \multicolumn{3}{|l|}{ Dictyochophyceae } \\
\hline Distephanus speculum & 9 & 30 \\
\hline Dictyocha fibula var. stapedia & 0 & 4 \\
\hline Pseudochattonella verruculosa & 0 & 27 \\
\hline \multicolumn{3}{|l|}{ Raphidophyceae } \\
\hline Fibrocapsa japonica & 30 & 17 \\
\hline Chattonella ovata & 1 & 0 \\
\hline Chattonella antiqua & 2 & 0 \\
\hline Chattonella marina & 0 & 0 \\
\hline \multicolumn{3}{|l|}{ Dinophyceae } \\
\hline Cochlodinium polykrikoides & 0 & 0 \\
\hline Karenia mikimotoi & 0 & 0 \\
\hline Heterocapsa circularisquama & 0 & 0 \\
\hline Dinophysis spp. & 1 & 0 \\
\hline Akashiwo sanguinea & 0 & 1 \\
\hline Gymnodinium spp. & 1 & 0 \\
\hline Noctiluca scintillans & 1 & 0 \\
\hline Protoperidinium spp. & 3 & 4 \\
\hline Scrippsiella spp. & 1 & 0 \\
\hline Ceratium furca & 6 & 0 \\
\hline
\end{tabular}

5400 cells $\mathrm{ml}^{-1}$ at Stns $\mathrm{H} 2$ and $\mathrm{H} 31$, respectively. Chaetoceros spp. were the third most dominant diatom with concentrations of 1000 cells ml $\mathrm{m}^{-1}$ and 400 cells $\mathrm{ml}^{-1}$ at Stns $\mathrm{H} 2$ and H31, respectively.

Few algal cells of Heterocapsa circularisquama, Karenia mikimotoi, Chattonella marina, C. antiqua, and C. ovata, which are notorious for causing HABs in Japan and frequently occur in the research area in summer, were observed in the seawater columns at both Stns H2 and H31 throughout the sampling period (Fig. 3). In contrast, Cochlodinium polykrikoides, the other fish-killing dinoflagellate, was observed after the end of the diatom bloom and fluctuated around 6 to 12 cells ml-1 at Stn H31. C. polykrikoides cells also increased in number at Stn $\mathrm{H} 2$ and reached 15 cells ml $^{-1}$ on 15 August.

\section{Fluctuations of algicidal bacteria}

Bacteria that were algicidal against 1 species of dinoflagellate (Heterocapsa circularisquama) and 3 species of raphidophycean flagellates (Chattonella antiqua, Heterosigma akashiwo, and Fibrocapsa japonica) were enumerated independently by the MPN protocol (Imai et al. 1998). The MPN of bacteria algicidal against $H$. circularisquama (HC-killer) did not exceed $4 \mathrm{MPN} \mathrm{ml}^{-1}$, and in most cases, the MPNs were under the detectable limit (Fig. 4). The bacteria that were algicidal against $C$. antiqua, $H$. akashiwo, and F. japonica (raphidophycean flagellates) also fluctuated at relatively low concentrations $\left(<34 \mathrm{MPN} \mathrm{ml}^{-1}\right)$. However, $140 \mathrm{MPN} \mathrm{ml}^{-1}$ of bacteria algicidal against C. antiqua were enumerated at Stn H2 on 11 July, when the diatom bloom diminished.

\section{Viable heterotrophic bacteria in particle-associated and free-living form}

We enumerated viable heterotrophic bacteria in particle-associated and in free-living form in the seawater samples separately using the CFU on the ST10 ${ }^{-1}$ agar plates. Relatively large numbers of FLB were counted during the beginning of the research period (27 June to 11 July), when the bloom of diatoms developed and collapsed at both sites (Fig 5). FLB counts also fluctuated in accordance with the chl a concentration in the seawater columns at both Stns H2 and H31, except on 3 August. A peak of PAB counts in surface seawater was also observed at the beginning of July at Stn H31, although the PAB counts at Stn $\mathrm{H} 2$ did not change considerably during the whole research period. Interestingly, the concentration of PAB at the seawater depth of $1 \mathrm{~m}$ above the bottom $(9 \mathrm{~m})$ increased in August at Stn H31, but at that time, no chl a accumulation was observed in the seawater column. A weak positive correlation between the average concentrations of PAB and chl $a$ in the water column at Stn H31 $\left(\mathrm{R}^{2}=0.55\right)$ was observed.

\section{Algicidal ability in FLB and PAB isolates}

In total, 736 strains were isolated from the colonies formed on the ST10 ${ }^{-1}$ agar plates, and their algicidal activities were assessed against 6 species of marine microalgae: Karenia mikimotoi, Heterocapsa circularisquama, Cochlodinium polykrikoides, Chattonella antiqua, Heterosigma akashiwo, and Fibrocapsa japonica (Table 2). As a result, 118 strains of PAB isolates at Stn H2 and 133 strains at Stn H31 showed algicidal ability against 1 or more species of the microalgae assayed, corresponding to $52.7 \%$ (118/224) and $50.6 \%(133 / 263)$ of total PAB isolates, respectively. In contrast, only $20.1 \%(23 / 114)$ and $22.0 \%$ (32/135) of FLB isolates from Stns H2 and H31 could kill any of the 
6 species of microalgae. Interestingly, the percentages of algicidal bacteria in PAB and FLB isolates were rather stable regardless of sampling sites and water depths (Table 2).
Among the 55 algicidal bacterial strains isolated from the FLB fraction, $41(74 \%)$ could kill only 1 of the 6 microalgae assayed in the present study (Fig. 6). However, almost $80 \%$ of the 200 algicidal bacterial strains
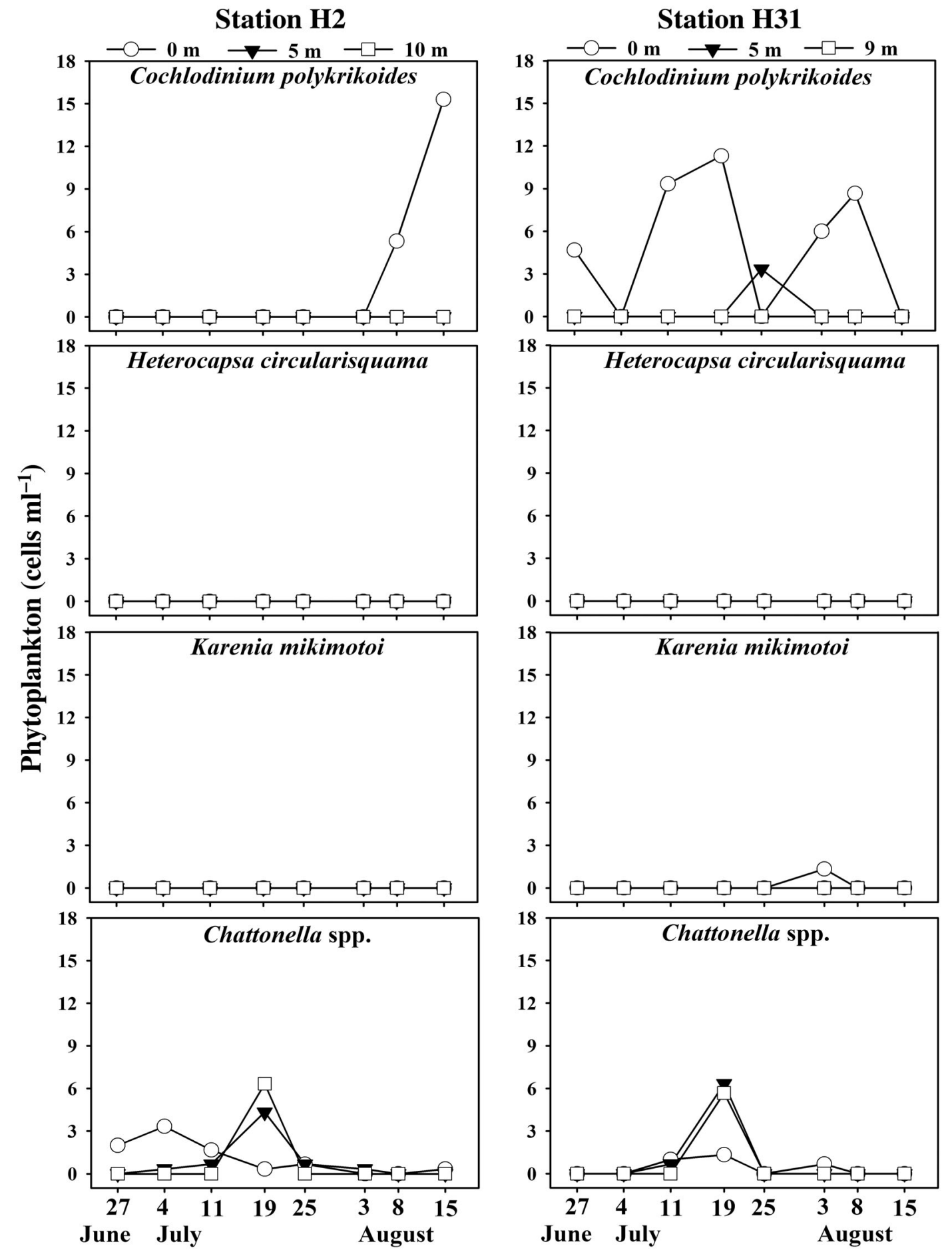

Fig. 3. Changes in concentrations of harmful dinoflagellates (Cochlodinium polykrikoides, Heterocapsa circularisquama, and Karenia mikimotoi) and harmful raphidophycean flagellates (Chattonella spp.: C. antiqua, C. marina, and C. ovata) at water depths of $0 \mathrm{~m}, 5 \mathrm{~m}$, and $10 \mathrm{~m}$ at Stn $\mathrm{H} 2$ and $0 \mathrm{~m}, 5 \mathrm{~m}$, and $9 \mathrm{~m}$ at Stn H31 in Harima-Nada from 27 June to 15 August 2005 
isolated from the PAB fraction had algicidal activities against more than 2 species of microalgae belonging to dinoflagellates and raphidophycean flagellates. Notably, 31 strains of PAB isolates could kill all 6 species of microalgae tested within 6 d of co-cultivation; no FLB isolate was capable of killing all 6 microalgae (Fig. 6). There was no significant difference in algicidal range among isolates from different water depths.
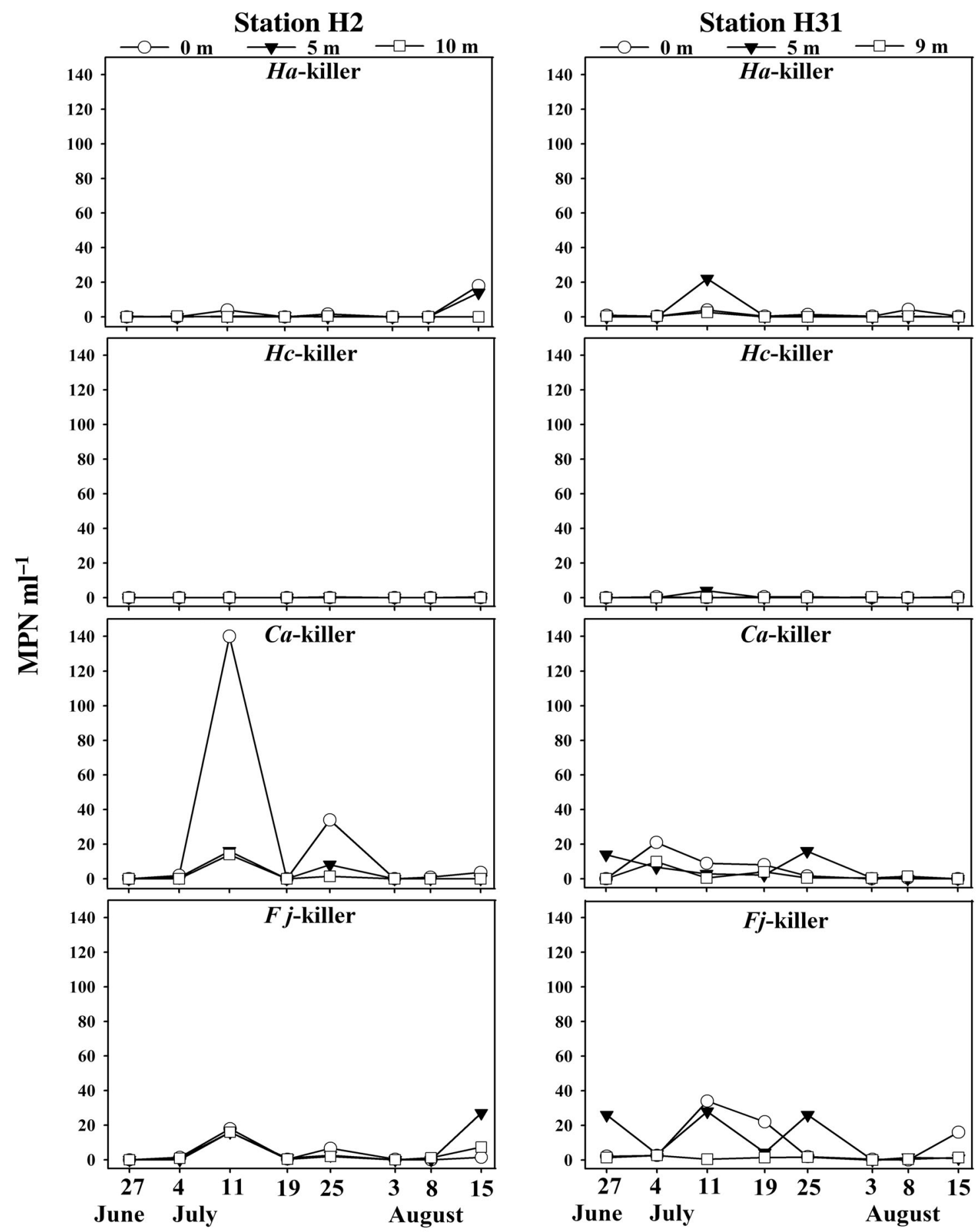

Fig. 4. Changes in concentration of the most probable number (MPN) of algicidal bacteria against Heterosigma akashiwo (Hakiller), Heterocapsa circularisquama (HC-killer), Chattonella antiqua (Ca-killer), and Fibrocapsa japonica (Fj-killer) at water depths of $0 \mathrm{~m}, 5 \mathrm{~m}$, and $10 \mathrm{~m}$ at Stn $\mathrm{H} 2$ and $0 \mathrm{~m}, 5 \mathrm{~m}$, and $9 \mathrm{~m}$ at Stn H31 in Harima-Nada from 27 June to 15 August 2005 


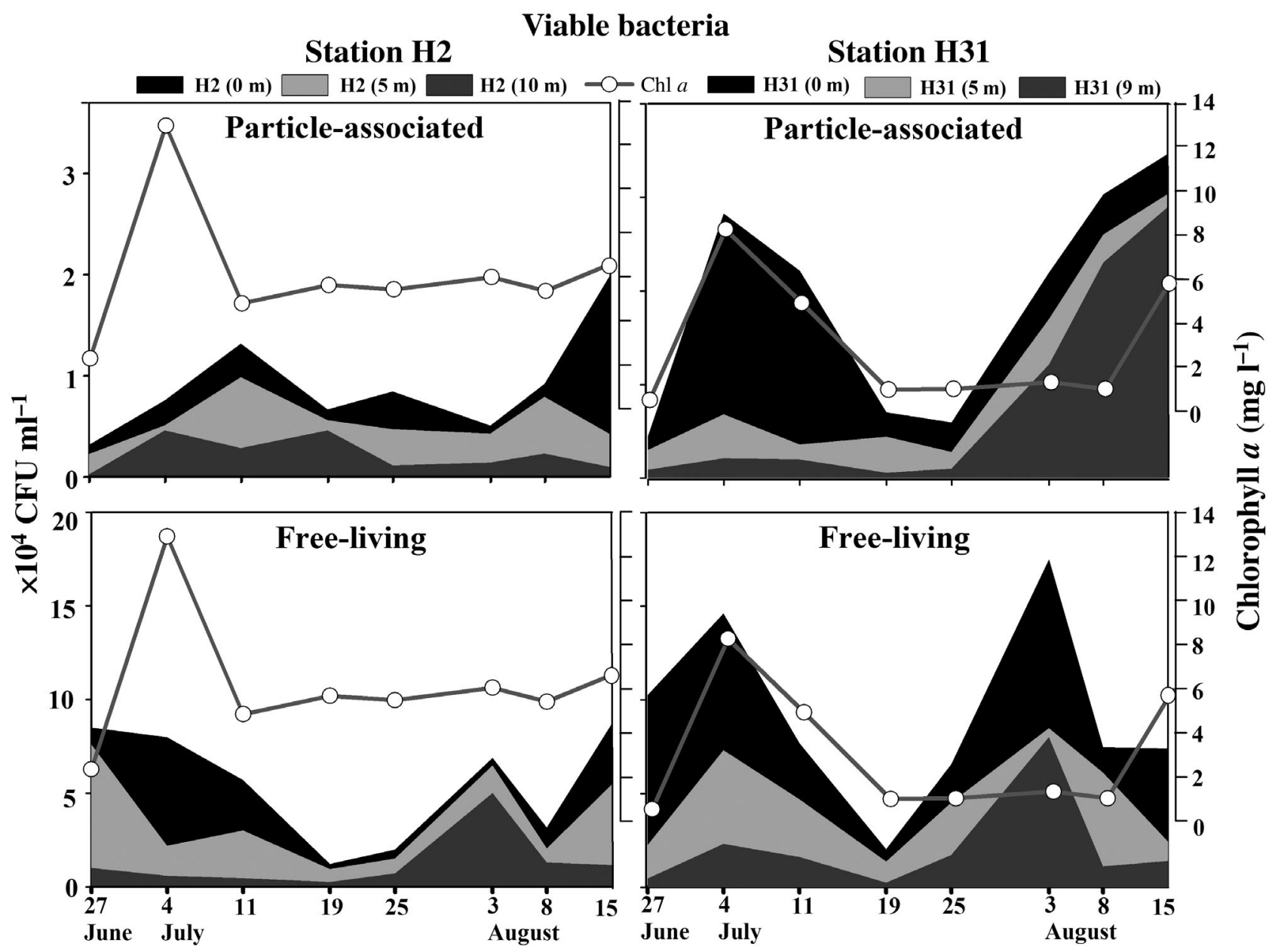

Fig. 5. Stacked graphs showing changes in the concentration of viable bacteria in particle-associated form (top panels) and in free-living form (bottom panels) in the seawater column at Stns H2 and H31 in Harima-Nada from 27 June to 15 August 2005. Viable bacterial concentrations at $0 \mathrm{~m}, 5 \mathrm{~m}$, and the deepest sampling depth (10 and $9 \mathrm{~m}$ for Stns H2 and H31, respectively) are shown. The average values of chlorophyll a concentrations at the 3 depths are also shown

Table 2. Numbers of algicidal bacteria among the fractions of particle-associated bacteria (PAB) and free-living bacteria (FLB) isolated from seawater samples collected at Stns H2 and H31 from 4 July to 15 August 2005

\begin{tabular}{|cccccccc|}
\hline \multirow{2}{*}{$\begin{array}{l}\text { Depth } \\
(\mathrm{m})\end{array}$} & $\begin{array}{c}\text { Total } \\
\text { isolates }\end{array}$ & $\begin{array}{c}\text { Algicidal } \\
\text { bacteria }\end{array}$ & $\begin{array}{c}\text { \% algicidal } \\
\text { bacteria }\end{array}$ & & $\begin{array}{c}\text { Total } \\
\text { isolates }\end{array}$ & $\begin{array}{c}\text { Algicidal } \\
\text { bacteria }\end{array}$ & $\begin{array}{c}\text { \% algicidal } \\
\text { bacteria }\end{array}$ \\
\hline PAB & & & & & & & \\
0 & 195 & 100 & 51.3 & & 221 & 111 & 50.2 \\
5 & 15 & 6 & 40.0 & & 18 & 8 & 44.4 \\
10 & 14 & 12 & 85.7 & & 24 & 14 & 58.3 \\
Total & 224 & 118 & 52.7 & & 263 & 133 & 50.6 \\
FLB & & & & & & \\
0 & 38 & 8 & 21.1 & & 42 & 9 & 21.4 \\
5 & 40 & 9 & 22.5 & & 47 & 11 & 23.4 \\
9 & 36 & 6 & 16.7 & & 46 & 12 & 26.1 \\
Total & 114 & 23 & 20.2 & 135 & 32 & 23.7 \\
& & & & & & & \\
\hline
\end{tabular}

\section{DISCUSSION}

Many reports have demonstrated that, just after the peak of algal blooms, algicidal bacteria targeting the bloom-forming microalgae increase in seawater columns (Fukami et al. 1991, Imai et al. 1998, 2001, Kim et al. 1998). These observations were often interpreted as an antagonistic relationship between algicidal bacteria and their prey microalgae, involving bacterial acquisition from organic nutrients by microalgal cells (Roth et al. 2008). Many researchers have speculated that such a relationship is a major cause of the sudden disappear- 

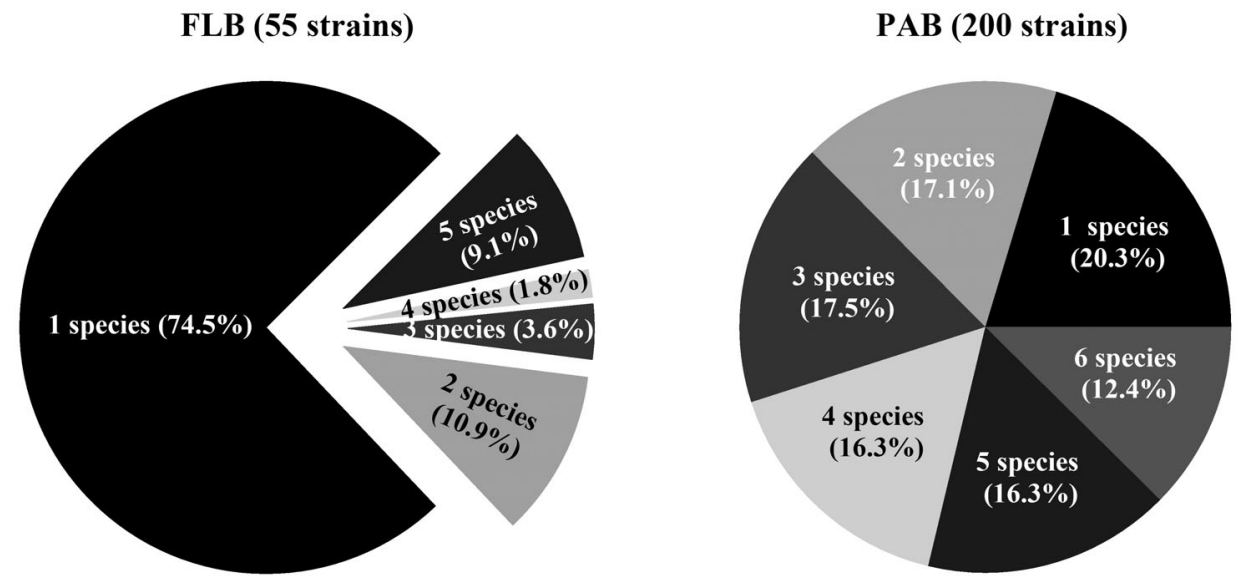

Fig. 6. Prey range of algicidal bacteria in free-living form (free-living bacteria; FLB) and in particle-associated form (particleassociated bacteria; PAB) in a co-cultivation assay with 3 species of dinoflagellates (Cochlodinium polykrikoides, Heterocapsa circularisquama, Karenia mikimotoi), and with 3 species of raphidophytes (Chattonella antiqua, Heterosigma akashiwo, and Fibrocapsa japonica). Numbers of microalgal species killed by bacterial isolates are shown in the pie chart. All algicidal isolates shown in Table 2 were analyzed

ance of algal blooms as is frequently observed in nature, while others have hypothesized that the destruction of microalgal blooms provides organic nutrient-rich environments that promote heterotrophy of bacterial communities that contain algicidal bacteria (Imai et al. 2001, Mayali \& Azam 2004). In any case, algal blooms should influence heterotrophic bacteria in both the free-living and the particle-associated form. In the present study, we observed a positive correlation between the concentration of chl a and viable heterotrophic bacteria (CFU) in the seawater column (Fig. 5). In particular, abundant heterotrophic bacteria (CFU) were observed at the beginning of July when microalgal blooms occurred at both Stns H2 and H31. This result indicates that the photosynthesized and dissolved organic nutrients excreted from microalgae affect the growth and activity of heterotrophic bacteria in ambient seawater.

Algicidal bacteria enumerated by the MPN method fluctuated at a low concentration $\left(<34 \mathrm{MPN} \mathrm{ml}^{-1}\right)$, except for bacteria algicidal against Chattonella antiqua (Ca-killer) throughout the research period (Fig. 4). The result of the MPN method with a liquid algal culture suggested that algicidal bacteria in a seawater sample can grow and prevail against other bacteria in a microalgae-bacteria co-culture. Furthermore, as has been pointed out in previous papers (Yoshinaga et al. 1995, Kim et al. 1998), a group of bacteria that promote algal growth can live alongside algicidal bacteria in natural environments. Finally, the killing of microalgae in the microplate wells in the present study may be determined by the sum of activities of co-existing bacteria. The number of algicidal bacteria calculated by the conventional MPN method is probably an under- estimate. Despite such biases, the MPN protocol demonstrated a prominent increase in Ca-killers in the surface layer at Stn H2 on 11 July, the date when the microalgae bloom disintegrated (Fig. 4). The bloom (4 July) was mainly composed of diatoms (Skeletonema costatum, Thalassiosira spp., and Chaetoceros spp.) and a few raphidophycean cells including Chattonella antiqua (Table 1). This result indicates the possibility that the diatom bloom promoted the growth of Ca-killers in ambient seawater at both sites. C. antiqua is one of the representative harmful microalgae that cause blooms and damage the fisheries in HarimaNada. Therefore, the increase in Ca-killers induced by the diatom bloom might act as a potential restraint to the Chattonella populations in the Seto Inland Sea.

In our MPN protocol, the algicidal bacteria attached to micro-scale particles were excluded from the enumeration by filtering the sample through 0.8 to $1.2 \mu \mathrm{m}$ pores (Imai et al. 1998, Kim et al. 1998). This filtration process is necessary to preclude the predation of examined microalgae by zooplankton, heterotrophic nanoflagellates, and ciliates, and nutrient competition with other microalgae in seawater samples. Otherwise, it has been shown that several isolates of algicidal bacteria need to attach to the target algae for killing and lysing (a direct attack) (Imai et al. 1993). This suggests that the algicidal bacterial population attaches to the particles in marine environments (microalgal cells are considered to be significant substrata for bacterial attachment in seawater columns). Therefore, the conventional MPN protocol with pre-filtration eliminates the algicidal bacterial population on particles.

In the present study, we compared the algicidal bacterial populations in free-living and particle-associated 
form. For this purpose, we first isolated FLB and PAB and assayed the algicidal activities of each. As a result, the PAB population, regardless of sampling depths and sites, was found to include more algicidal bacteria than the FLB population (Table 2). Furthermore, most PAB isolates could kill 2 or more species of microalgae, whereas only 20 to $22 \%$ of the FLB isolates could do so (Fig. 6). This result strongly suggests that particulate matter floating in seawater accumulates algicidal bacteria that have a wide prey range (algicidal against multiple species of dinoflagellates and raphidophycean flagellates used in the present study).

Many algicidal bacteria with wide a prey range have been isolated from seawater environments. For example, Kim et al. (1999) isolated several strains of algicidal bacteria from the southern sea area of Korea that could kill a species of diatom, Chaetoceros sp., as well as Chattonella antiqua. Moreover, it has been reported that bacterial species of the Flexibacter/Cellulophaga/ Bacteroides subgroup mainly consist of algicidal bacteria that use the killing process of 'direct attack' and have a wide prey range (Imai et al. 1993, Lovejoy et al. 1998). These previous findings and the results of our study suggest that the algicidal bacterial populations that attach to the particles, especially to the bloomcausing diatom cells, are potential agents restricting algal blooms caused by various species of microalgae.

Symbiotic bacteria exist on diatom cells in mutual (Smith et al. 1995) or commensal (Smith et al. 1995) relationships, which convey protection against algicidal pressure (Mayali \& Doucette 2002). However, it is likely that a commensal or mutual relationship of symbiotic bacteria shifts to a parasitic form when the environment becomes unfavorable for the bacteria (Mayali \& Azam 2004) and they express algicidal activity against the diatom cells to which they are attached. Grossart \& Simon (2007) described isolated bacteria that inhibit or promote the growth of the marine diatom Thalassiosira rotula depending on the concentration of inorganic nutrients, vitamins, and trace elements, indicating a shift of the phytoplankton-bacteria relationship, which can change from a symbiotic or mutual relationship to a parasitic one, or vice versa. Unfortunately, we could not prepare an axenic (bacteria-free) culture of diatoms and could not obtain any information on bacteria that were algicidal against the bloom-forming diatom species. It is possible that the algicidal bacteria associated with particles in the present study played a role in the disintegration of diatom blooms as well as the restriction of HABs.

There remains a question over whether Ca-killers in the FLB fraction, which were counted by the MPN method after pre-filtration through a $0.8 \mu \mathrm{m}$ pore size filter and prominently increased in number at the end of the diatom bloom in July, were derived from the PAB fraction or not. We purified several strains of algicidal bacteria from the MPN culture, determined their 16S rRNA gene sequences, and compared them to those of PAB isolates that show algicidal activity. We obtained a variety of phylotypes (= ribotypes) of algicidal bacteria from the MPN culture and PAB isolates (data not shown), but the phylogenetic affiliations of several isolates from the MPN culture were similar to those of algicidal bacteria isolated from the PAB fraction. This result indicates that some algicidal bacteria that originally grew on particles (particle-associated form) might have dissociated and moved out to ambient sea water (free-living form), and were detected by the conventional MPN method.

In the present study, we propose a new perspective that microalgal blooms (in our case, a diatom bloom) not only promote the growth and heterotrophic activity of ambient bacterial populations, but also provide adequate habitats as substrata for algicidal bacteria with a wide prey range. Moreover, these bacteria also fuction as a potential restraint on occurrences of HABs caused by dinoflagellates and raphidophycean flagellates. In coastal environments, particles floating in the seawater column should originate from zooplankton, animals, and terrestrial substances besides phytoplankton. In our study, the number of PAB increased in the deeper layer in August at Stn H31, the nearshore site, regardless of the low abundance of microalgae in the surface layer. It is probable that the origins and compositions of particles at H31 might change seasonally, but we do not have any information about this. More information on the species composition, physiological characteristics, killing mechanisms, and ecological features of algicidal bacteria in the PAB fraction should be elucidated to shed more light on the interrelated dynamics of algicidal bacterial and microalgal populations in coastal sea environments.

Acknowledgements: We thank S. Sawayama for critical reading of the manuscript. We also thank H. Kim for helpful advice and encouragement. This study was supported in part by a grant from the Fisheries Agency of Japan and also by a grantin-aid for scientific research (No. 16380131) from the Ministry of Education, Culture, Sports, Science, and Technology, Japan.

\section{LITERATURE CITED}

Bidle KD, Fletcher M (1995) Comparison of free-living and particle-associated bacterial communities in the Chesapeake Bay by stable low-molecular-weight RNA analysis. Appl Environ Microbiol 61:944-952

Blodgett R (1998) Appendix 2: Most probable number determination from serial dilutions. In: Bacteriological analytical manual, 8th edn. US Food and Drug Administration. www.fda.gov/Food/ScienceResearch/LaboratoryMethods/ BacteriologicalAnalyticalManualBAM/default.htm 
Buskey EJ (2008) How does eutrophication affect the role of grazers in harmful algal bloom dynamics? Harmful Algae 8:152-157

Doucette GJ, McGovern ER, Babinchak JA (1999) Algicidal bacteria active against Gymnodinium breve (Dinophyceae). I. Bacterial isolation and characterization of killing activity. J Phycol 35:1447-1454

Fukami K, Nishijima T, Murata H, Doi S, Hata Y (1991) Distribution of bacteria influential on the development and the decay of Gymnodinium nagasakiense red tide and their effects on algal growth. Nippon Suisan Gakkaishi 57: 2321-2326

Fukami K, Nishijima T, Ishida Y (1997) Stimulative and inhibitory effects of bacteria on the growth of microalgae. Hydrobiologia 358:185-191

> Grossart HP, Simon M (2007) Interactions of planktonic algae and bacteria: effects on algal growth and organic matter dynamics. Aquat Microb Ecol 47:163-176

Grossart HP, Kiørboe T, Tang K, Ploug H (2003) Bacterial colonization of particles: growth and interactions. Appl Environ Microbiol 69:3500-3509

Imai I, Kimura S (2008) Resistance of the fish-killing dinoflagellates Cochlodinium polykrikoides against algicidal bacteria isolated from the coastal sea of Japan. Harmful Algae 7:360-367

Imai I, Ishida Y, Hata Y (1993) Killing of marine phytoplankton by a gliding bacterium Cytophaga sp., isolated from the coastal sea of Japan. Mar Biol 116:527-532

Imai I, Kim MC, Nagasaki K, Itakura S, Ishida Y (1998) Relationships between dynamics of red tide-causing raphidophycean flagellates and algicidal microorganisms in the coastal sea of Japan. Phycol Res 46:139-146

Imai I, Sunahara T, Nishikawa T, Hori Y, Kondo R, Hiroishi S (2001) Fluctuations of the red tide flagellates Chattonella spp. (Raphidophyceae) and the algicidal bacterium Cytophaga sp. in the Seto Inland Sea, Japan. Mar Biol 138: 1043-1049

Jackson CR, Weeks AQ (2008) Influence of particle size on bacterial community structure in aquatic sediments as revealed by $16 \mathrm{~S}$ rRNA gene sequence analysis. Appl Environ Microbiol 74:5237-5240

Kim MC, Yoshinaga I, Imai I, Nagasaki K, Itakura S, Ishida Y (1998) A close relationship between algicidal bacteria and termination of Heterosigma akashiwo (Raphidophyceae) blooms in Hiroshima Bay, Japan. Mar Ecol Prog Ser 170: 25-32

Kim MC, Yu HS, Ok MS, Kim CH, Chang DS (1999) The activities and characteristics of algicidal bacteria in Chindong Bay. J Korean Fish Soc 32:359-367

Kim MJ, Jeong SY, Lee SJ (2008) Isolation, identification, and algicidal activity of marine bacteria against Cochlodinium polykrikoides. J Appl Phycol 20:1069-1078

Long RA, Azam F (2001) Microscale patchiness of bacterio-

Editorial responsibility: Staffan Kjelleberg,

Sydney, Australia plankton assemblage richness in seawater. Aquat Microb Ecol 26:103-113

Lovejoy C, Bowman JP, Hallegraeff GM (1998) Algicidal effects of a novel marine Pseudoalteromonas isolate (class Proteobacteria, gamma subdivision) on harmful algal bloom species of the genera Chattonella, Gymnodinium, and Heterosigma. Appl Environ Microbiol 64:2806-2813

Manabe T, Tanda M (1986) A method for automated, simultaneous analysis of reactive silicate, reactive phosphate, ammonia, nitrite and nitrate in sea water. Umi Sora 1:25-37 (in Japanese, with English abstract)

- Marcarelli AM, Wurtsbaugh WA, Griset O (2006) Salinity controls phytoplankton response to nutrient enrichment in the Great Salt Lake, Utah, USA. Can J Fish Aquat Sci 63: $2236-2248$

Mayali X, Azam F (2004) Algicidal bacteria in the sea and their impact on algal blooms. J Eukaryot Microbiol 51: $139-144$

Mayali X, Doucette GJ (2002) Microbial community interactions and population dynamics of an algicidal bacterium active against Karenia brevis (Dinophyceae). Harmful Algae 1:277-293

Mitsutani A, Yamasaki I, Kitaguchi H, Kato J, Ueno S, Ishida Y (2001) Analysis of algicidal proteins of a diatom-lytic marine bacterium Pseudoalteromonas sp strain A25 by two-dimensional electrophoresis. Phycologia 40:286-291

Nagasaki K, Brussaard CPD (2008) Algal viruses. In: Mahy BWJ, van Regenmortel MHV (eds) Encyclopedia of virology, 3rd edn. Academic Press, Oxford, p 97-105

Pannard A, Bormans M, Lagadeuc Y (2008) Phytoplankton species turnover controlled by physical forcing at different time scales. Can J Fish Aquat Sci 65:47-60

Roth PB, Twiner MJ, Mikulski CM, Barnhorst AB, Doucette GJ (2008) Comparative analysis of two algicidal bacteria active against the red tide dinoflagellate Karenia brevis. Harmful Algae 7:682-691

> Smith DC, Steward GF, Long RA, Azam F (1995) Bacterial mediation of carbon fluxes during a diatom bloom in a mesocosm. Deep-Sea Res II 42:75-97

Yoshinaga I, Kawai T, Takeuchi T, Ishida Y (1995) Distribution and fluctuation of bacteria inhibiting the growth of a marine red tide phytoplankton Gymnodinium mikimotoi in Tanabe Bay (Wakayama Pref Japan). Fish Sci 61: 780-786

Yoshinaga I, Kawai T, Ishida Y (1997) Analysis of algicidal ranges of the bacteria killing the marine dinoflagellates Gymnodinium mikimotoi isolated from Tanabe Bay, Wakayama Pref, Japan. Fish Sci 63:94-98

Yoshinaga I, Kim MC, Katanozaka N, Imai I, Uchida A, Ishida Y (1998) Population structure of algicidal marine bacteria targeting the red tide forming alga Heterosigma akashiwo (Raphidophyceae), determined by restriction fragment length polymorphism analysis of the bacterial $16 \mathrm{~S}$ ribosomal RNA genes. Mar Ecol Prog Ser 170:33-44

Submitted: December 3, 2009; Accepted: March 3, 2010

Proofs received from author(s): May 12, 2010 